\title{
Insulin-like growth factor I, IGF binding protein 3 , and IGFBP protease activity: relation to anthropometric indices in solid tumours or leukaemia
}

\author{
B M D Brennan, M Gill, L Pennells, O B Eden, A G Thomas, P E Clayton
}

Department of

Paediatric Oncology, Manchester Children's Hospitals, Manchester M27 4HA, UK

B M D Brennan

O B Eden

Department of Gastroenterology, Manchester Children's

Hospitals

A G Thomas

Endocrine Science

Research Group,

University of

Manchester,

Manchester M13 9PT,

UK

M Gill

L Pennells

P E Clayton

Correspondence to:

Dr P E Clayton, Department of Paediatric Endocrinology, Royal Manchester Children's Hospital, Pendlebury,

Manchester M27 4HA, UK.

Accepted 24 September 1998

\begin{abstract}
Objectives-To measure the serum concentrations of insulin-like growth factor I (IGF-I) and IGF binding protein 3 (IGFBP-3), and the level of IGFBP-3 protease activity in 38 children presenting with malignancies, and to assess their relation with auxological parameters and nutritional status.

Methods-Height, weight, skinfold thickness, and mid-upper arm circumference (MUAC) were recorded using standard techniques. IGF-I and IGFBP-3 were measured using specific radioimmunoassays. Serum IGFBPs were also visualised on western ligand blot. IGFBP-3 protease activity was assessed by the extent of fragmentation of recombinant $\left[{ }^{125} I\right]-I G F B P-3$, compared with that induced by pregnancy serum. Anthropometric and radioimmunoassay data were expressed as standard deviation scores (SDS).
\end{abstract}

Results-The median (range) IGF-I SDS was significantly reduced in all patients $(-1.1(-5.1$ to 1.2$))$ and lower in children who were malnourished $(-2.5 \quad(-3.9$ to $0.1)$. IGFBP-3 SDS was within the normal range for 31 of 38 patients but IGFBP-3 protease activity was raised in all patients. Neither IGFBP-3 concentration nor protease activity was affected by nutritional status. IGF-I correlated with MUAC $(r=0.41)$ and subscapular skinfold thickness SDS $(r=0.38)$, but not with weight, height, weight for height, or triceps skinfold thickness.

Conclusions-IGF-I is low in children with malignancies, and even lower in those who are malnourished. IGFBP-3 concentrations were normal in most patients but interpretation is complicated by the presence of raised IGFBP-3 protease activity, which could lead to overestimating concentrations of intact peptide. IGF-I appears to relate to arm anthropometry as an index of nutritional status but not height, weight, or weight for height, as would be expected in normal children. (Arch Dis Child 1999;80:226-230)

Keywords: insulin-like growth factor I; insulin-like growth factor binding protein 3; protease activity; malignancy; nutrition; growth
Malnutrition in children with malignancies is a considerable problem. It can be assessed by anthropometric measurements such as weight, height, and weight for height, ${ }^{1}$ skinfold thickness and mid-arm circumference, ${ }^{2}$ or plasma proteins such as albumin, ${ }^{3}$ prealbumin, and retinol binding protein. ${ }^{4}$

Insulin-like growth factor I (IGF-I) is a mitogenic polypeptide the function of which is modified by specific IGF-I binding proteins, IGFBP-1 to $-7 .{ }^{56}$ Most circulating IGF-I is held in a ternary complex comprising IGF-I, IGFBP-3, and an acid labile subunit. Serum concentrations of IGF-I are significantly correlated to serum IGFBP-3 and growth hormone, with nutrition being a further major regulator of IGF-I. ${ }^{7-9}$ IGF-I and IGFBP-3 are significantly decreased in states of severe malnutrition, ${ }^{10}$ such as anorexia nervosa.

The relation between IGF-I and IGFBP-3 can be modified further by specific IGFBP proteases, which degrade IGFBP-3 into smaller fragments that have a decreased affinity for IGF-I and hence increase IGF-I bioavailability. Indeed, previous work by Muller et al demonstrated increased IGFBP protease activity in children with malignancies. ${ }^{11}$

Our study aimed to measure the serum concentrations of IGF-I and IGFBP-3 and the level of IGFBP-3 protease activity in children presenting with malignancies, and to assess the effect of both malignancy and nutritional status, defined by auxiological parameters, on IGF-I and IGFBP-3.

\section{Patients and methods}

PATIENTS

Thirty eight children (median age, 4.7 years; range, 0.5-15.8) with either solid malignant tumours $(n=26)$ or acute leukaemia $(n=12)$ were studied at presentation, before the initiation of treatment, which included surgery, chemotherapy, or radiotherapy. Table 1 gives the exact diagnoses. Subjects were enrolled in our study after informed consent was obtained from their parents. The presence of any other condition associated with failure to thrive or poor growth led to exclusion. Our study had the approval of the local ethics committee.

SERUM SAMPLES

We obtained blood samples from the children after an overnight fast, at a time when venepuncture was carried out for clinical reasons. Blood was then centrifuged and the 
Table 1 Diagnosis of children with malignancies

\begin{tabular}{ll}
\hline Diagnosis & Number \\
\hline Acute leukaemia & 12 \\
Renal tumour & 7 \\
Neuroblastoma & 5 \\
Hodgkin's disease & 3 \\
Rhabdomyosarcoma & 2 \\
Germ cell tumour & 2 \\
Liver tumour & 2 \\
B-cell non-Hodgkin's lymphoma & 2 \\
Nasopharyngeal carcinoma & 1 \\
Bone tumour & 2 \\
\hline
\end{tabular}

serum separated and stored at $-70^{\circ} \mathrm{C}$ until analysis.

ANTHROPOMETRY

We performed anthropometric assessments in all patients. Height (or supine length), weight, mid-upper arm circumference (MUAC), triceps skinfold thickness (TSFT), and subscapular skinfold thickness (SSFT) were all measured by one observer (BMDB) using standard techniques. ${ }^{12-14}$ Weight was expressed as weight for height, in accordance with the recommendations of the WHO. ${ }^{15}$ We considered a child to be malnourished if any one of the following criteria was fulfilled: (1) a weight for height of less than $85 \%$; (2) MUAC less than the fifth centile $^{13}$; (3) any skinfold thickness less than the third centile. ${ }^{14}$

\section{IGF-I RADIOIMMUNOASSAY}

We determined the serum IGF-I concentration by radioimmunoassay (RIA) (Nichols Institute Diagnostics, San Juan Capistrano, California, USA), following acid/ethanol extraction of its binding proteins. Assay sensitivity was $8.4 \mu \mathrm{g} / 1$. The interassay coefficient of variation $(\mathrm{CV})$ was $5.2-8.4 \%$ and the intra-assay $\mathrm{CV}$ was 2.4 $3 \%$.

IGFBP-3 RIA

We determined the serum IGFBP-3 concentration by RIA (Nichols Institute Diagnostics). Assay sensitivity was $0.06 \mathrm{mg} / \mathrm{l}$. The interassay CV was $5.3-6.3 \%$ and the intra-assay $C V$ was $3.4-8 \%$. Age and sex matched normal ranges (mean (2 SD)) for IGF-1 and IGFBP-3 were provided by the Nichols Institute.

WESTERN LIGAND BLOT ANALYSIS OF IGFBPS

We carried out western ligand blot analysis of the IGFBPs, as described originally by Hossenlope et $a l,{ }^{16}$ on 36 serum samples. Briefly, $5 \mu \mathrm{l}$ samples were diluted $1 / 10$ in loading buffer

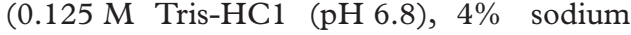
dodecyl sulphate (SDS), 20\% glycerol, $0.25 \%$ bromophenol blue) and heated for five minutes at $100^{\circ} \mathrm{C}$. Samples were then electrophoresed through an SDS polyacrylamide gel (3\% stacking gel $/ 10 \%$ separating gel) at $175 \mathrm{~V}$ for four hours. After electrophoresis, proteins were electroblotted on to a nitrocellose membrane at $30 \mathrm{~V}$ overnight. The membrane was washed in Nonidet NP-40 (3\%), $0.15 \mathrm{M}$ $\mathrm{NaCl}, 1 \mathrm{M}$ Tris, $0.5 \%$ sodium azide at $4{ }^{\circ} \mathrm{C}$ for 30 minutes, blocked in $0.15 \mathrm{M} \mathrm{NaCl}, 1 \% \mathrm{BSA}$ for 90 minutes at room temperature, and incubated with 150000 counts/minute $\left[{ }^{125} \mathrm{I}\right]-\mathrm{IGF}-\mathrm{I}$ for four hours at room temperature. Finally, the membrane was washed twice with $0.15 \mathrm{M}$ $\mathrm{NaC} 1$ for 15 minutes at room temperature. The dried membrane was exposed to a phosphoimaging plate and $44 \mathrm{kDa}$ to $38 \mathrm{kDa}$ bands were quantified using a Fuji Bioimaging analyser (Fuji Photofilm Co, Tokyo, Japan). Normal adult serum was run as a control. Results were expressed as absorption units $(\mathrm{AU}) / \mathrm{mm}$.

ASSESSMENT OF IGFBP-3 PROTEOLYTIC ACTIVITY We assayed serum samples for IGFBP-3 proteolytic activity by a modification of the method of Lamson and colleagues. ${ }^{17}$ In brief, $3 \mu \mathrm{l}$ of serum was incubated with nonglycosylated recombinant $\left[{ }^{125} \mathrm{I}\right]-\mathrm{IGFBP}-3$ in assay buffer $\left(0.5 \mathrm{mM} \mathrm{CaCl}_{2}\right.$ in phosphate buffered saline) overnight at $37^{\circ} \mathrm{C}$. Subsequently, the samples were diluted with loading buffer $(0.125 \mathrm{M}$ Tris- $\mathrm{HCl}$ ( $\mathrm{pH} 6.8), 4 \%$ SDS, $20 \%$ glycerol, and $0.25 \%$ bromophenol blue) and then electrophoresed through a nonreducing SDS polyacrylamide gel (3\% stacking gel $15 \%$ separating gel). The gel was dried, exposed to $x$ ray film, and proteolysed $\left[{ }^{125} \mathrm{I}\right]-$ IGFBP-3 bands were quantitated by densiometry. As controls for the assay, the following samples were run on each gel: (1) $\left.{ }^{125} \mathrm{I}\right]-$ IGFBP-3 in assay buffer; (2) [ $\left.{ }^{125} \mathrm{I}\right]-\mathrm{IGFBP}-3$ in assay buffer, incubated overnight; (3) pooled pregnancy serum and $\left[{ }^{125} \mathrm{I}\right]-\mathrm{IGFBP}-3$; and (4) pooled pregnancy serum, $\left[{ }^{125} \mathrm{I}\right]-\mathrm{IGFBP}-3$, and a protease inhibitor $(10 \mathrm{mM}$ phenylmethylsulphonylfluoride (PMSF)). The proteolytic activity in each serum sample was expressed as a percentage of that found in the pooled pregnancy serum. According to previous studies, ${ }^{18}{ }^{19}$ protease activity exceeding $30 \%$ of that found in pregnancy serum was considered to be raised.

\section{STATISTICAL ANALYSIS}

Data were expressed as the median with range. Statistical analysis was performed using nonparametric tests. Comparisons with age and sex matched reference data (results expressed as SD scores) were performed using the Wilcoxon matched pairs signed rank test. Comparison between the groups was made by the Mann-Whitney $U$ test, and relations between variables by Spearman correlation.

\section{Results}

The median (range) SD scores for weight, height, and weight for height were $-0.31(-3.6$ to 2.8$),-0.1$ ( -1.8 to 3.6$)$, and -0.1 ( -2.8 to $2.7)$, respectively, which were not significantly different from normal. In contrast, the median SD scores (range) for MUAC, TSFT, and SSFT were -1.0 ( -5.1 to 1.2$),-0.8$ ( -4.1 to 3.1 ), and -1.0 ( -3.4 to 2.5 ), respectively, which were significantly different from normal (all $\mathrm{p}<0.01$ ). This dichotomy between arm anthropometry and weight and height related indices held for the subgroup of solid tumours but not for those patients with acute leukaemia (table 2). Only one child with acute leukaemia was malnourished but 13 of the 26 children with solid tumours fulfilled the definition of malnutrition. All patients satisfied the 
Table 2 Median (range) anthropometric standard deviation scores in patients with solid tumours and acute leukaemia

\begin{tabular}{lll}
\hline & Solid tumours & Leukaemia \\
\hline Height & $-0.2(-1.9$ to 1.3$)$ & $-0.04(-0.7$ to 3.6$)$ \\
Weight & $-0.4(-3.6$ to 1.9$)$ & $-0.3(-1.2$ to 2.8$)$ \\
Weight $/$ height & $0.1(-2.8$ to 1.9$)$ & $-0.2(-1.6$ to 2.7$)$ \\
MUAC & $-1.3(-3.9 \text { to } 1.8)^{\star}$ & $-0.7(-1.3$ to 2.5$)$ \\
TSFT & $-0.9(-4.1 \text { to } 2.7)^{\star}$ & $-0.5(-1.5$ to 3.2$)$ \\
SSFT & $-1.4(-3.4 \text { to } 2.3)^{\star}$ & $0.6(-1.5$ to 3.2$)$ \\
\hline
\end{tabular}

${ }^{\star} \mathrm{p}<0.01$.

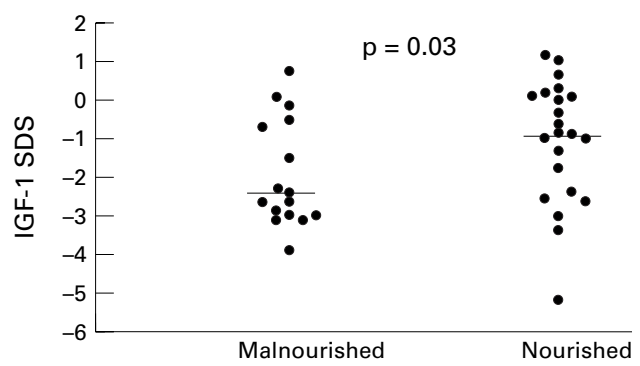

Figure 1 IGF-I SD scores in malnourished $(n=14)$ and nourished $(n=24)$ tumour patients. Horizontal bars represent the median values.

definition of malnutrition based on arm anthropometry. However, all but four of these malnourished patients had normal weight related indices as a result of the assumed tumour mass contributing to the weight.

The median (range) IGF-I SD scores were significantly different from normal in the whole group $(-1.1(-5.1$ to 1.2$) ; \mathrm{p}<0.01)$, in the solid tumour group $(-1.4(-3.9$ to 1.2$)$; $\mathrm{p}<0.01)$, and in the acute leukaemia group $(-0.9$ ( -5.1 to 0.7$) ; \mathrm{p}<0.01)$. The median (range) SD score of IGF-I of the 14 malnourished children was -2.5 ( -3.9 to 0.1$)$, which was significantly lower than that of the 24 nourished children, $(-0.8 \quad(-5.1$ to 1.2$)$; $\mathrm{p}=0.03$ ) (fig 1). However, there was considerable overlap in the IGF-I values between the two groups. The significant difference in IGF-I

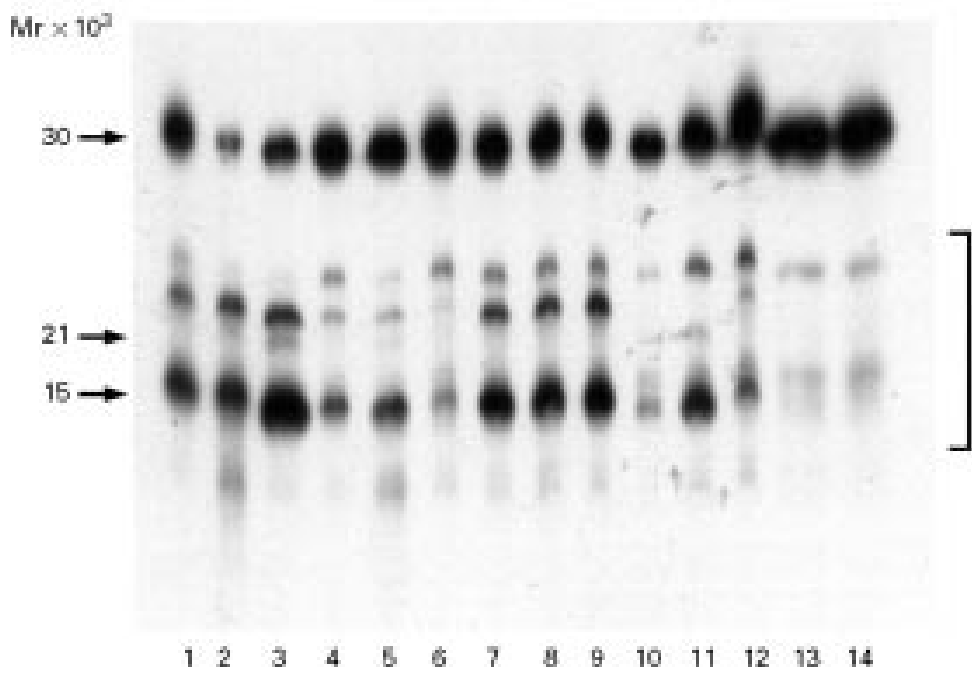

Figure 2 [25I]-IGFBP-3 protease assay on sera from patients (lanes 1-9); pooled pregnancy serum and $10 \mathrm{mM}$ protease inhibitor phenylmethylsulphonylfluoride (lane 10);

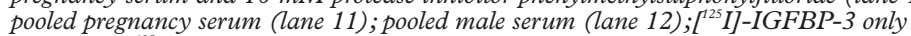
(lane 13); [125IJ-IGFBP-3 incubated overnight at $37^{\circ} \mathrm{C}$ (lane 14). Molecular size markers are indicated on the left, and the bracket on the right indicates the proteolysed $\left.{ }^{125} I\right]-I G F B P-3$ fragments measured by densiometry.
SD scores between nourished and malnourished children remained in the solid tumour subgroup, where the median (range) IGF-I SD scores for the malnourished $(\mathrm{n}=13)$ and nourished $(\mathrm{n}=13)$ children were $-2.4(-3.9$ to 0.1$)$ and $0.7(-2.9$ to 1.2$)$, respectively $(\mathrm{p}=0.02)$.

In contrast to the IGF-I SD score, the median (range) IGFBP-3 SD scores were not significantly different from normal in either the whole group ( $0.2(-10.2$ to 1.5$) ; \mathrm{p}=0.7)$, the subgroups of acute leukaemia $(1.0(-3.1$ to $1.7) ; \mathrm{p}=0.6)$, or solid tumours $(0.1(-10.2$ to $1.5) ; \mathrm{p}=0.8)$. IGF-I was significantly correlated with IGFBP-3 for the whole group $(r=0.7 ; \mathrm{p}<0.001)$.

Serum concentrations of IGFBP-3 were within $2 \mathrm{SD}$ of the mean in 31 subjects but IGFBP-3 was only detected by western ligand blot in 16 of 36 patients. There was no correlation between IGFBP-3 detected on western ligand blot and IGFBP-3 measured by RIA in the whole group $(r=0.3 ; \mathrm{p}=0.2)$ IGFBP-3 proteolysis was present in serum from all patients with the appearance of a $15-23 \mathrm{kDa}$ band (fig 2). The median (range) protease activity of the whole group was 138\% (43$213 \%$ ) of pooled pregnancy serum. There was no significant difference in protease activity between malnourished and nourished subjects, median (range) protease activity was $127 \%$ $(72-213 \%)$ and $140 \%$ (43-195\%), respectively. In addition, there was no significant difference in protease activity between those with solid tumours and those with leukaemia.

Again, in contrast to the IGF-I SD score, the IGFBP-3 SD score was not significantly different between the malnourished and nourished children: median (range) IGFBP-3 SD scores of malnourished and nourished groups were $-0.2(-10.2$ to 1.5$)$ and $0.4(-4.2$ to 1.4$)$, respectively, $(p=0.2)$. There were no differences in IGFBP-3 SD scores between the nourished and malnourished solid tumour patients.

Both MUAC and SSFT SD scores correlated positively with IGF-I SD scores $(r=0.41, \mathrm{p}=0.02 ; r=0.38, \mathrm{p}=0.03$, respectively), but not with IGFBP-3 SD scores $(r=0.3, \mathrm{p}=0.06 ; r=0.3, \mathrm{p}=0.08$, respectively). There was no correlation between weight, height, weight for height, and TSFT SD scores and either IGF-I or IGFBP-3 SD scores.

\section{Discussion}

We have shown that the serum IGF-I SD score is significantly reduced in children with malignancies at presentation, and even lower in those who are also malnourished. Furthermore, IGF-I relates to arm anthropometry as an index of nutritional status but not to height, weight, or weight for height, as would be expected in normal children.

In children with Wilms' tumour, serum IGF-I concentrations have been reported to be no different from a control group. However, nutritional status in these patients was not stated..$^{20}$ In contrast, Mohnike et al assessed serum IGF-I concentrations in 15 children 
with acute leukaemia at presentation and found that the mean IGF-I SD score was reduced to $-3.0 .^{21}$ The SD score returned to normal during chemotherapy, despite severe nutritional problems.

Low IGF-I concentrations have been found in children with protein energy malnutrition. ${ }^{82}$ Soliman et al reported low serum IGF-I concentrations in 51 children with malnutrition, ${ }^{23}$ which increased after nutritional rehabilitation. IGF-I was a more sensitive index of nutritional status than serum albumin, correlating both with the expected weight for age and cross sectional arm fat.

Short term dietary restriction also affects IGF-I concentrations in normal children. ${ }^{24} \mathrm{~A}$ calorie reduction of $50 \%$ caused a significant decline in IGF-I concentrations within six days in eight normal children. Protein restriction had a similar effect. In our study, serum IGF-I concentrations were low for the whole group, despite the fact that only half the subjects were malnourished. However, IGF-I concentrations were lower in the malnourished subgroup. It is likely that in all our children the energy and protein intake would be reduced before tumour diagnosis, with the malnourished subjects suffering the more intense and prolonged nutrient restriction and hence showing a greater reduction in IGF-I concentrations.

Acute dietary changes do not affect IGFBP-3, its concentration remaining stable during the day and being unaffected by meals. ${ }^{25}$ However, in states of prolonged severe malnutrition, such as anorexia nervosa, IGFBP-3 is significantly decreased, together with IGF-I. ${ }^{10}$ In addition, calorie restriction to $50 \%$ of normal intake significantly decreased IGFBP-3 in children but not in adults, while protein restriction had no effect on IGFBP-3 in children, but caused a modest decrease in adults. $^{24}$

Serum concentrations of IGFBP-3 as measured by RIA were not significantly reduced in our patients and did not correlate with IGFBP-3 measured by western ligand blot. In fact, IGFBP-3 was not detected by western ligand blot in over half of the subjects. This suggested that IGFBP-3 protease activity could be increased, and this was confirmed by the protease assay. These findings agree with those of Muller et $a l^{11}$ who found normal IGFBP-3 concentrations and raised IGFBP-3 protease activity in 34 children with solid tumours and leukaemia. This discrepancy results from the ability of the RIA to recognise IGFBP-3 fragments produced by proteases, generating falsely normal or even high concentrations of serum IGFBP-3. The lower affinity of the IGFBP-3 fragments for IGF-I will also tend to raise the bioavailability of IGF-I. The net effect on IGF-I action will thus depend on the opposing influences of reduction in IGF-I concentrations and a rise in IGFBP-3 protease activity.

Oster et al predicted that IGFBP-3 proteases would be more active in severe protein and/or calorie malnutrition. ${ }^{26}$ However, their experiments in protein and calorie restriction of young adult rats failed to show an increase in IGFBP-3 specific protease activity, despite a fall in IGF-I and IGFBP-3 concentrations. IGFBP-3 protease activity was increased in all our patients, malnourished and nourished, implying that the malignancy rather than the nutritional status was the trigger to increased protease activity.

In our study, IGF-I concentrations correlated with arm anthropometry and skinfold thickness but not with height, weight, or weight for height. Our findings might be explained by the poor reliability of weight related indices in the assessment of nutritional status in children with malignancies. ${ }^{2}$ Because arm anthropometry is independent of tumour mass, and hence probably a better indicator of nutritional status, our findings of a positive correlation between MUAC or SSFT and IGF-I SD scores support those of Smith et al. ${ }^{2}$

In animal models, serum IGF-I concentrations are significantly reduced in dietary restricted rats, concomitant with a decrease in cancer incidence. ${ }^{22}$ In fact, correction of the lowered IGF-I by exogenous IGF-I in diet restricted, heterozygous p53 deficient mice, induced to develop a preneoplastic bladder lesion with $p$-cresidine, increased cancer stage and decreased apoptosis rates. ${ }^{27}$ Therefore, it is possible that the low IGF-I concentrations found in our study are important in limiting tumour progression.

IGF-I is low at presentation in children with malignancies and even lower in those who are malnourished. There is, however, considerable overlap between IGF-I concentrations in nourished and malnourished groups, indicating that it is not a reliable test of nutritional status. Serum IGFBP-3 is normal in children with malignancies, and has no relation to nutritional status. Its interpretation is complicated by the presence of raised IGFBP-3 protease activity. The disruption of the normal relation between IGF-I and IGFBP-3 appears to result from a number of factors, including the presence of the tumour itself and nutritional status. Strategies to maintain the relatively low IGF-I concentrations found in these children and to reverse their increased IGFBP-3 protease activity, thus minimising IGF-I bioavailability, could be important in limiting tumour progression.

1 Donaldson SS, Wesley MN, DeWys WD, Suskind RM, Jaffe $\mathrm{N}$, vanEys J A. A study of the nutritional status of pediatric cancer patients. Am f Dis Child 1981;135:1107-12.

2 Smith DE, Stevens MCG, Booth IW. Malnutrition at diagSmith DE, Stevens MCG, Booth IW. Malnutrition at diag-
nosis of malignancy in childhood: common but mostly nosis of malignancy in childhood: co
missed. Eur F Pediatr 1991;150:318-22.

3 Merritt RJ, Kalsch M, Roux LD, Ashley-Mills J, Siegel SS. Significance of hypoalbuminemia in pediatric oncology patients-malnutrition or infection. FPEN $f$ Parenter Enteral Nutr 1985;9:303-6.

4 Uderzo C, Rovelli A, Bonomi M, et al. Nutritional status in untreated children with acute leukaemia as compared with children without malignancy. $\mathcal{F}$ Pediatr Gastroenterol Nutr 1996;23:34-7.

5 Clemmons DR. IGF binding protein; regulation of cellular actions. Growth Regul 1992;2:80-7.

6 Oh Y, Nagalla SR, Yamanake Y, Kim H-O, Wilson E, Rosenfeld R. Synthesis and characterisation of insulin-like growth factor binding protein (IGFBP)-7. F Biol Chem 1996;271:30322-5.

7 Clemmons DR, Klibanski A, Underwood LE, et al. Reduction of plasma immunoreactive somatomedin $\mathrm{C}$ during fasting in humans. F Clin Endocrinol Metab 1981;53:124750 . 
8 Hintz RL, Suskind R, Amatayakul K, Thanangkul O, Olson R. Plasma somatomedin and growth hormone values in children with protein-calorie malnutrition. 7 Pediatr 1978 92:153-6.

9 Grant DB, Hambley J, Becker D, Pimstone BL. Reduced sulphation factor in undernourished children. Arch Dis Child 1973;48:596-600

10 Counts DR, Gwirtsman H, Carlsson LMS, Lesem M, Cutler GB Jr. The effect of anorexia nervosa and refeeding on growth hormone-binding protein, the insulin-like growth factors (IGFs) and IGF-binding proteins. $\mathcal{F}$ Clin Endocrinol Metab 1992;75:762-7.

11 Muller HL, Youngman OH, Gargosky SE, Wilson KF, Lehrnbecher T, Rosenfeld RG. Insulin-like growth factor binding protein-3 concentrations and insulin-like growth factor binding protein- 3 protease activity in sera of patients with malignant solid tumours or leukaemia. Pediatr Res 1994;35:720-4.

12 Tanner JM, Whitehouse RH, Takaishi M. Standards from birth to maturity for height, weight, height velocity, and birth to maturity for height, weight, height velocity, and weight velocity: British

13 Frisancho AR. New norms of upper limb fat and muscle areas for assessment of nutritional status. Am $\mathcal{F}$ Clin Nut 1981;34:2540-5.

14 Tanner JM, Whitehouse RH. Revised standards for triceps and subscapular skinfolds in British children. Arch Dis Child 1975;50:142-5.

15 World Health Organisation. Measuring change in nutritional status 1983. Geneva: WHO, 1983.

16 Hossenlope P, Seurin D, Segovia-Quinson B, Hardouin S, Binoux M. Analysis of serum insulin-like growth factor binding proteins using western blotting: use of the method for tritiation of the binding proteins and competitive binding studies. Annal Biochem 1986;154:138-43.

17 Lamson G, Giudice LC, Rosenfeld RG. A simple assay for proteolysis of IGFBP-3. F Clin Endocrinol Metab 1991;72: proteolysis

18 Gargosky SE, Pham HM, Wilson KF, Liu F, Giudice LC, Rosenfeld RG. Measurements and characterization of insulin-like growth factor binding protein-3 in human bioand ligand blotting. Endocrinology 1992;131:3051-60.
19 Muller HL Youngman OH, Gargosku SE, Lehrnbecher T, Hintz RL, Rosenfield RG. Concentrations of insulin-like growth factor (IGF)- binding protein-3 (IGFBP-3), IGF, and IGFBP-3 protease activity in cerebrospinal fluid of children with leukaemia, central nervous system tumor, or meningitis. F Clin Endocrinol Metab 1993;77:1113-19.

20 Zumkeller W, Schwander J, Mitchell CD, Morrell DJ, Schofield PN, Preece MA. Insulin-like growth factor (IGF)-I, -II and IGF binding protein-2 (IGFBP-2) in the plasma of children with Wilms' tumour. Eur F Cancer 1993; 29A:1973-7.

21 Mohnike K, Blum WF, Mittler U, Kluba U, Ranke MB. IGF-I, IGF-II, IGFBP-3 serum levels are suppressed in acute lymphoblastic leukaemia (ALL) and increase during therapy [abstract]. Horm Res 1992;37:55.

22 Weindruch $\mathrm{R}$, Walford RL. The retardation of aging and disease by dietary restriction. Springfield, IL: C Thomas, 1988.

23 Soliman AT, Hassan AEHI, Aref MK, Hintz RL, Rosenfeld RG, Rogol AD. Serum insulin-like growth factors I and II concentrations and growth hormone and insulin responses to arginine infusion in children with protein-energy malnutrition before and after nutritional rehabilitation. Pediatr Res 1986;20:1122-30.

24 Smith WJ, Underwood LE, Clemmons DR. Effects of caloric or protein restriction on insulin-like growth factor-I (IGF-I) and IGF-binding proteins in children and adults. $\mathcal{F}$ Clin Endocrinol Metab 1995;80:443-9.

25 Cotterill AM, Cowell CT, Baxter RC, McNeil C, Silinik M. Regulation of the hormone-independent growth factorbinding protein in children. 7 Clin Endocrinol Metab 1988; 67:882-7.

26 Oster MH, Fielder PJ, Levin N, Cronin MJ. Adaptation of the growth hormone and insulin-like growth factor-I axis to chronic and severe calorie or protein malnutrition. $\mathcal{F}$ Clin Invest 1995;95:2258-65.

27 Dunn SE, Kari FW, French J, et al. Dietary restriction reduces insulin-like growth factor I levels, which modulates apoptosis, cell proliferation, and tumour progression in p53-deficient mice. Cancer Res 1997;57:4667-72. 